\title{
ROLE OF FERRITIN IN THE RICE TOLERANCE TO IRON OVERLOAD
}

\author{
Vivian Chagas da Silveira ${ }^{1}$; Cristina Fadanelli²; Raul Antonio Sperotto ${ }^{1}$; Ricardo José Stein ${ }^{1}$; \\ Luiz Augusto Basso ${ }^{5}$; Diógenes Santiago Santos ${ }^{5}$; Itabajara da Silva Vaz Junior ${ }^{1,3}$; Johnny \\ Ferraz Dias ${ }^{4}$; Janette Palma Fett ${ }^{1,2 *}$ \\ ${ }^{1}$ UFRGS - Centro de Biotecnologia - C.P. 15005 - 91501-970 - Porto Alegre, RS - Brasil. \\ ${ }^{2} U F R G S$ - Depto. de Botânica. \\ ${ }^{3} U F R G S$ - Faculdade de Veterinária. \\ ${ }^{4} U F R G S$ - Instituto de Física. \\ ${ }^{5}$ PUCRS - Centro de Pesquisas em Biologia Molecular e Funcional - 90619-900 - Porto Alegre, RS - Brasil. \\ *Corresponding author <jpfett@cbiot.ufrgs.br>
}

\begin{abstract}
Plants ordinarily face iron (Fe) deficiency, since this mineral is poorly available in soils under aerobic conditions. Nonetheless, wetland and irrigated rice plants can be exposed to excess, highly toxic Fe. Ferritin is a ubiquitous Fe-storage protein, important for iron homeostasis. Increased ferritin accumulation resulting from higher Fe availability was shown in some plant species. However, the role of ferritin in tolerance mechanisms to Fe overload in rice is yet to be established. In this study, recombinant rice ferritin was expressed in Escherichia coli, producing an anti-rice ferritin polyclonal antibody which was used to evaluate ferritin accumulation in two rice (Oryza sativa L.) cultivars, either susceptible (BR-IRGA 409) or tolerant (EPAGRI 108) to Fe toxicity. Increased ferritin mRNA and protein levels resulting from excess Fe treatment were detected in both cultivars, with higher ferritin protein accumulation in EPAGRI 108 plants, which also reached lower shoot Fe concentrations when submitted to iron overload. The tolerance mechanism to excess Fe in EPAGRI 108 seems to include both restricted Fe translocation and increased ferritin accumulation. This is the first work that shows higher accumulation of the ferritin protein in an iron-excess tolerant Oryza sativa cultivar, providing evidence of a possible role of this protein in iron tolerance mechanisms.
\end{abstract}

Key words: PIXE, anti-ferritin antiserum, metal tolerance

\section{PAPELDAFERRITINANATOLERÂNCIADE ARROZ AO EXCESSO DE FERRO}

RESUMO: Deficiência de ferro (Fe) ocorre freqüentemente em plantas, uma vez que este mineral é pouco disponível em condições aeróbicas. Plantas de arroz cultivadas sob alagamento, no entanto, estão sujeitas ao excesso de Fe, que pode ser extremamente tóxico. Alguns cultivares de arroz são resistentes a altas concentrações de ferro, mas os mecanismos fisiológicos responsáveis por essa resistência são pouco conhecidos. A ferritina é uma proteína de ampla distribuição e capaz de armazenar ferro, sendo considerada importante para a homeostase deste metal. Acúmulo de ferritina em condições de alta disponibilidade de ferro já foi descrito em algumas espécies vegetais. Entretanto, o papel da ferritina no mecanismo de tolerância de plantas de arroz ao excesso de ferro não é conhecido. Neste trabalho, expressamos ferritina de arroz em E. coli, produzimos um anticorpo policlonal anti-ferritina de arroz e este foi utilizado para avaliar o acúmulo de ferritina em dois cultivares de arroz (Oryza sativa) considerados suscetível (BR-IRGA 409) e tolerante (EPAGRI 108) ao excesso de ferro. O anticorpo foi capaz de reconhecer ferritina purificada de sementes de ervilha, assim como ferritina de folhas de arroz. Aumentos nos níveis de mRNA e proteína foram observados nos dois cultivares sob excesso de ferro, com maior acúmulo da proteína no cultivar EPAGRI 108. Quando submetidas a excesso do elemento, plantas deste mesmo cultivar atingiram concentrações de Fe mais baixas do que plantas do cultivar BR-IRGA409, principalmente nas partes aéreas. Sugere-se que o mecanismo de tolerância ao excesso de ferro no cultivar EPAGRI 108 inclui limitação da translocação de Fe e aumento do acúmulo de ferritina. Este é o primeiro trabalho que mostra maior acúmulo da proteína ferritina em um cultivar de Oryza sativa tolerante ao excesso de Fe, fornecendo evidência de um possível papel desta proteína nos mecanismos de tolerância a este metal. Palavras-chave: PIXE, anti-soro anti-ferritina, tolerância a metal 


\section{INTRODUCTION}

Iron $(\mathrm{Fe})$ homeostasis must be closely regulated in plants. Although essential, excess Fe is toxic, causing oxidative stress in plant cells (Guerinot \& Yi, 1994). When cultivated in waterlogged conditions, which increase Fe solubility, rice plants can face Fe overload (Sahrawat, 2004). Total grain weight reduction of 50\% has been reported on rice plants with leaf Fe concentrations higher than $250 \mu \mathrm{g} \mathrm{g}^{-1}$ dry weight (Genon et al., 1994). Rice genotypes vary in their resistance to Fe excess, and the mechanisms underlying resistance are not well understood. Some rice cultivars seem to rely on avoidance mechanisms, limiting Fe uptake and especially Fe translocation to shoots; others are fairly tolerant to high leaf Fe concentrations.

Ferritin is considered crucial for Fe homeostasis. It consists of a multimeric spherical protein able to store up to $4,500 \mathrm{Fe}$ atoms inside its central cavity in a non-toxic and bioavailable form (Briat et al., 2006). Plant ferritin is found mainly in plastids, and also in mitochondria (Zancani et al., 2007). Increased ferritin mRNA and protein abundance have been reported in Arabidopsis and maize plants supplied with excess Fe or under increased Fe availability during leaf senescence, although with different induction pathways, kinetics and organ distribution of ferritin isoforms (Lobréaux et al., 1992; Petit et al., 2001; Murgia et al., 2007). Pea mutants with excessive Fe accumulation have higher ferritin levels in leaves than WT (Wild Type) plants (Becker et al., 1998). These species, however, do not face Fe overload in nature, as do wetland and irrigated rice. The importance of ferritin synthesis in tolerance mechanisms to Fe excess in rice remains to be investigated.

Two ferritin genes have been identified in the rice genome by Gross et al. (2003). Ferritin gene regulation by Fe has been documented in rice only for the African species Oryza glaberrima Steud (Majerus et al., 2007). As a first step to study ferritin importance and regulation in Oryza sativa plants, recombinant rice ferritin was produced and used to generate a polyclonal antibody, a tool for future ferritin studies in rice. This study demonstrates differential ferritin protein accumulation in two rice cultivars, susceptible and tolerant to Fe overload.

\section{MATERIALAND METHODS}

\section{Cloning and expression of rice ferritin genes}

Two clones (D22266 and AU064475) corresponding to full-length ferritin cDNAs (OsFer1 and OsFer2, respectively) were kindly provided by the MAFF DNA Bank from the National Institute of Agrobiological Sci- ences, Tsukuba, Japan. The primers used for cloning of ferritin cDNAs were designed to amplify the full length of the sequences encoding the mature protein, being added of restriction sites for NdeI at the 5' region and BamHI at the 3' region. The forward primer was 5' TGCATATGGCCGCCGGGAAAGGGAAGGAG 3'; with the NdeI site underlined and the codon encoding the first amino acid from the mature protein highlighted in bold. The reverse primer was 5' CGGATCCTCAAGCTTCTTCCTCAAGCAGCTTC 3', with the BamHI site underlined and the reverse complement of the codon relative to the termination of translation highlighted in bold. The 644 bp products were amplified using the following PCR conditions: $3 \mathrm{~min}$ at $98^{\circ} \mathrm{C}$ followed by 35 cycles of $45 \mathrm{~s}$ at $98^{\circ} \mathrm{C}, 45 \mathrm{~s}$ at $65^{\circ} \mathrm{C}$, and $1 \mathrm{~min} 30 \mathrm{~s}$ at $72^{\circ} \mathrm{C}$; the final extension was $10 \mathrm{~min}$ at $72^{\circ} \mathrm{C}$, using $P f u$ Turbo DNA Polymerase (Stratagene). The PCR products were analyzed on $1.5 \%$ agarose gel, purified using the Matrix Gel Extraction Protocol Kit (GibcoBRL), cloned in pCR-Blunt (Invitrogen) and electroporated into E. coli TOP 10. Individual colonies resistant to Kanamycin were grown on liquid medium and plasmid DNA extracted and digested with NdeI (Gibco) and BamHI (Boeringher). The PCR amplified fragments were excised from agarose gels and cloned into the pET23a(+) (Novagen) expression vector using standard procedures. The recombinant clones obtained were sequenced to confirm the insert identity. The recombinant plasmids and the empty vector pET23a $(+)$ were transformed into electrocompetent $E$. coli BL21(DE3) cells, and selected on LB agar plates containing $50 \mu \mathrm{g}$ $\mathrm{mL}^{-1}$ of carbenicillin. Positive clones were grown at $37^{\circ} \mathrm{C}$ in $25 \mathrm{~mL} \mathrm{LB}$ medium with $50 \mu \mathrm{g} \mathrm{mL}^{-1}$ carbenicillin for $20 \mathrm{~h}$ in the presence or absence of $0.4 \mathrm{mM}$ IPTG (isopropyl $\beta$-D-1-thiogalactopyranoside). Cells were harvested by centrifugation at 14,000 rpm for 3 min and pellets were suspended in $500 \mu \mathrm{L}$ of $50 \mathrm{mM}$ Tris-HCl, pH 7.8 and sonicated. After centrifugation at $14,000 \mathrm{rpm}$ for $20 \mathrm{~min}$ at $4^{\circ} \mathrm{C}$, the soluble extract was carefully separated from the residual cells. The soluble protein extracts were analyzed on denaturing $15 \%$ SDS-PAGE.

\section{Antibody production and testing by Western blot analysis}

Recombinant protein produced from clone AU064475 was used for antibody production. One rabbit was inoculated four times at 15 days intervals by intraperitoneal route with about $400 \mu \mathrm{g}$ of recombinant protein. Protein concentration was determined according to Bradford (1976). Rabbit blood was collected before the first inoculation and after fifteen days of the forth inoculation. To test the specificity of the 
antibody, E. coli culture samples expressing the ferritin cDNA were induced with IPTG, collected, and the corresponding protein extracts were separated by SDS-PAGE (15\%), transferred to PVDF membranes (via semi-dry transfer cells) and allowed to stand overnight. Membranes were blocked in Blotto [phosphatebuffered saline (PBS: $100 \mathrm{mM} \mathrm{Na} \mathrm{HPO}_{4}, 17 \mathrm{mM}$ $\mathrm{KH}_{2} \mathrm{PO}_{4}, 1.4 \mathrm{M} \mathrm{NaCl}$ and $27 \mathrm{mM} \mathrm{KCl}$ ) containing $5 \%$ skim milk, $0.02 \%$ sodium azide and $0.02 \%$ Tween 20] at room temperature for $2 \mathrm{~h}$. Membranes were then incubated with serum diluted in Blotto overnight. Serum pre-immune was diluted 50 times and immune serum was diluted 200, 400, 800, 1,600 and 3,200 times. At the next day, membranes were washed and incubated with anti- IgG rabbit - peroxidase (Sigma Aldrich, 1:2,000 dilution) in $\mathrm{NaCl} 150 \mathrm{mM}$, Tris- $\mathrm{HCl}$ $50 \mathrm{mM} \mathrm{pH} 7.5$ and 5\% skim milk for $1 \mathrm{~h}$. Membranes were washed in $\mathrm{NaCl} 150 \mathrm{mM}$, Tris- $\mathrm{HCl} 50 \mathrm{mM}$ pH 7.5 and ferritin bands were revealed in a solution of $0.01 \mathrm{M}$ Tris-HCl $\mathrm{pH}$ 7.5, $0.6 \mathrm{mg} \mathrm{mL}$ DAB (diaminobenzidine), $0.03 \% \mathrm{CoCl}_{2}$ and $1 \mu \mathrm{L} \mathrm{mL}^{-1} \mathrm{H}_{2} \mathrm{O}_{2}$ $30 \%$.

\section{Plant growth}

Rice (Oryza sativa L. ssp. indica) seeds from cultivars EPAGRI 108 (E108) and BR-IRGA 409 (I409) were provided by IRGA (Instituto Rio Grandense do Arroz, Brazil). These cultivars have been previously characterized as tolerant and susceptible to Fe toxicity (Nava \& Bohnen, 2002; Silveira et al., 2007). After germination and growth in vermiculite and nutrient solution (Yoshida et al., 1976) for 14 days in an incubator $\left(28^{\circ} \mathrm{C}\right.$, first two days in the dark and remaining days with $16 \mathrm{~h}$ of light), plants were transferred to glass pots covered with aluminum foil and containing $500 \mathrm{~mL}$ of nutrient solution. Each pot harbored four plants, held by a styrofoam lid, and plants were kept for $10 \mathrm{~d}$ in growth solution, modified from Yoshida et al. (1976) to contain $3.2 \mathrm{mg} \mathrm{L}^{-1} \mathrm{Fe}$ as $\mathrm{FeCl}_{2} \cdot 6 \mathrm{H}_{2} \mathrm{O}$ combined to citric acid in a 2:1 (citric acid:Fe) ratio, $\mathrm{pH} 5.0 \pm 0.1$. Plants were then transferred to treatments, with the following modifications from the Yoshida solution: excess $\mathrm{Fe}\left(500 \mathrm{mg} \mathrm{L}^{-1} \mathrm{Fe}\right.$ as $\mathrm{FeSO}_{4} \cdot 7 \mathrm{H}_{2} \mathrm{O}$, solution $\mathrm{pH} 4.2 \pm 0.1$ ), control $(6.5 \mathrm{mg}$ $\mathrm{L}^{-1} \mathrm{Fe}$ as $\mathrm{FeSO}_{4} .7 \mathrm{H}_{2} \mathrm{O}$ plus $500 \mathrm{mg} \mathrm{L}^{-1} \mathrm{~S}$ as $\mathrm{Na}_{2} \mathrm{SO}_{4}$, solution pH $5.1 \pm 0.1$ ), and Fe deficiency (no Fe added, with addition of $0.15 \mathrm{mM}$ Ferrozine, Sigma Aldrich). All solutions were replaced every three days. Plants were cultivated in a growth room at $26 \pm 1^{\circ} \mathrm{C}$ under a 16:8 h light:darkness photoperiod (irradiance $=100$ $\mu \mathrm{mol} \mathrm{m} \mathrm{s}^{-1}$ ).

\section{Iron determination}

Fe concentrations were determined in roots and shoots by the Particle Induced X-Ray Emission (PIXE) technique, as described by Silveira et al. (2007). Sampled roots or shoots from four plants were dried, ground and pressed into pellets. Measurements were obtained from three pellets for each treatment, obtained from three independent experiments. PIXE analyses were carried out at a 3 MV Tandetron accelerator facility. All measurements were performed using a 2 $\mathrm{MeV}$ proton beam with an average current of $5 \mathrm{nA}$. The acquisition time for each sample was $20 \mathrm{~min}$. The characteristic X-rays induced by the proton beam were detected by a standard PIXE experimental set-up using a high-purity Germanium detector (EG\&G Nuclear Instruments, GLP series, Oak Ridge, USA) with an energy resolution of $180 \mathrm{eV}$ at $5.9 \mathrm{KeV}$. The GUPIX code was used for data analysis (Campbell et al., 2000). The final uncertainties quoted for the elemental concentrations were evaluated taking into account the discrepancy of the independent measurements and the uncertainties arising from the least-square fitting procedure given by the GUPIX code.

\section{Protein extraction from rice leaves}

Approximately $100 \mathrm{mg}$ of fresh tissue from fully expanded leaves were ground in $1 \mathrm{~mL}$ of extraction buffer (50 mM Tris-HCl pH 8.0, 10\% sucrose, $1 \mathrm{mM}$ EDTA, $1 \mathrm{mM}$ PMSF, 0.01\% ortho-phenantrolin) for total protein extraction. After 10 min centrifugation at $15,000 \times g\left(4^{\circ} \mathrm{C}\right)$, the supernatant was collected and the protein concentration determined according to Bradford (1976). Protein samples were stored at $-20^{\circ} \mathrm{C}$ and $25 \mu \mathrm{g}$ of each sample was analyzed on $12.5 \%$ SDS-PAGE, according to Laemmli (1970). Western blots were performed as described, with anti-ferritin antiserum dilution of 1:100. Each experiment was performed at least twice. Representative blots are shown.

\section{Purification of ferritin from pea seeds}

Pea ferritin was purified from seeds using the protocol described by Laulhere et al. (1988) with modifications. Approximately $150 \mathrm{~g}$ of pea seeds were imbibed in $\mathrm{dH}_{2} \mathrm{O}$ for $2 \mathrm{~d}$ at $4^{\circ} \mathrm{C}$ under constant air bubbling. Next, seeds were homogenized with $300 \mathrm{~mL}$ of $50 \mathrm{mM}$ potassium phosphate $\mathrm{pH} 7.0$ containing 1\% polyvinylpirrolidone. After 10 min centrifugation at $10,000 \mathrm{rpm}$ at $4^{\circ} \mathrm{C}$ (STEP 1$), \mathrm{MgCl}_{2}$ was added to the supernatant to a final concentration of $50 \mathrm{mM}$, and a second centrifugation at $10,000 \mathrm{rpm}$ for $15 \mathrm{~min}$ at $4{ }^{\circ} \mathrm{C}$ was performed to precipitate debris and ribosomes (STEP 2). Twenty minutes after the $\mathrm{MgCl}_{2}$ addition, trisodium citrate and RNase A were added to final concentrations of $70 \mathrm{mM}$ and $10 \mu \mathrm{g} \mathrm{mL}{ }^{-1}$ to complex the magnesium and prevent ferritin precipitation. After 2 $\mathrm{h}$ at $4^{\circ} \mathrm{C}, 50 \mathrm{~mL}$ of this mixture was centrifuged $(15$ min at $10,000 \mathrm{rpm}, 4^{\circ} \mathrm{C}$ ) through $2 \mathrm{~mL}$ of $5 \mathrm{mM}$ potassium phosphate, $\mathrm{pH}$ 7.0, 0.01\% Triton X-100 and 
$50 \%$ glycerol. The pellets were ressuspended in $5 \mathrm{~mL}$ of potassium phosphate $7 \mathrm{mM}, \mathrm{pH} 7.0,0.006 \%$ Triton X-100 and 30\% glycerol (STEP 3) and maintained at $4^{\circ} \mathrm{C}$ overnight. After centrifugation at $10,000 \mathrm{rpm}$ for $15 \mathrm{~min}$ at $4^{\circ} \mathrm{C}$, the resulting brown pellet was ressuspended in $1 \mathrm{~mL}$ of $10 \mathrm{mM}$ potassium phosphate (STEP 4), and aliquots were maintained at $-20^{\circ} \mathrm{C}$. The purity of ferritin was confirmed by SDS-PAGE 15\%. Known amounts of protein (Bradford, 1976) from each purification step were filtered under pressure in $45 \mu \mathrm{m}$ Millipore paper, which was used for Fe quantification by PIXE, with irradiation of the opaque face of the filter, where samples where homogeneously distributed.

\section{RNA extraction, cDNA synthesis and semi-quan- titative RT-PCR}

Rice leaves from cultivars E108 and I409 were harvested from plants grown under control or Fe excess conditions for 9 days ( $n=4$ per each group). Total RNA was extracted using Trizol (Gibco BRL, Grand Island, NY, USA) and treated with DNase I (Invitrogen). For the synthesis of first strand cDNA, $1 \mu \mathrm{g}$ of total RNA from each treatment was reversetranscribed using an oligo- $\mathrm{dT}_{30}$ primer and Superscript II (Invitrogen) in the presence of RNase OUT (Invitrogen) in a $20 \mu \mathrm{L}$ reaction. The synthesized first strand cDNA was diluted five times and $2 \mu \mathrm{L}$ were used for PCR analysis with specific primers for ferritin. Primers used for ferritin amplification (forward 5'CCAAAGGGAAGGAGGTGCTC 3', reverse 5'GAATTCGCTCTCAACGAAG 3') were designed to amplify a region conserved in both ferritin isoforms previously described (Gross et al., 2003). The PCR conditions used were $95^{\circ} \mathrm{C}$ for $30 \mathrm{~s}, 60^{\circ} \mathrm{C}$ for $30 \mathrm{~s}$ and $72^{\circ} \mathrm{C}$ for $30 \mathrm{~s}$ in a $50 \mu \mathrm{L}$ volume. The appropriate number of PCR cycles was determined for each gene to ensure that amplification occurred in the linear range. The PCR amplified DNA fragment was analyzed by agarose gel electrophoresis stained with ethidium bromide. Amplification of ubiquitin (Miki et al., 2005) cDNA was used to normalize the data.

\section{RESULTS AND DISCUSSION}

Amplified cDNA fragments corresponding to the coding sequences of the two rice ferritin genes were cloned in pET $23 \mathrm{a}(+)$ and their identities confirmed by DNA sequencing. Both isoforms of rice ferritin were successfully expressed in E. coli under IPTG induction (Figure 1a). Recombinant ferritin expressed from the cDNA clone D22266 (OsFer1) was also expressed without IPTG induction (data not shown). Since the mature protein from both rice ferritin genes are pre-

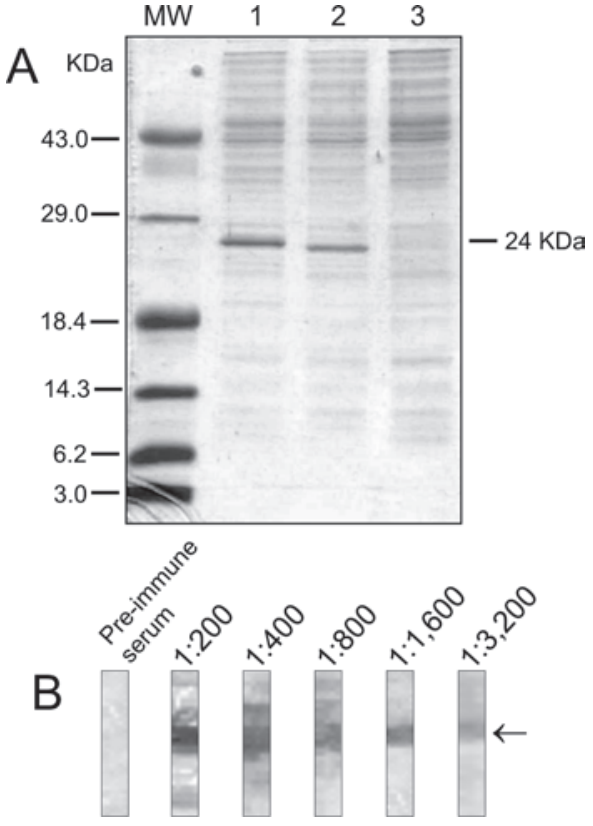

Figure 1 - (a) Ferritin expression in E. coli BL21(DE3) following IPTG induction. SDS-PAGE of soluble protein fractions. MW: molecular weight marker; 1 : Soluble proteins (total $10.2 \mu \mathrm{g}$ ) from $E$. coli transformed with the vector containing the D22266 ferritin cDNA (OsFer1); 2: Soluble proteins (total $8.3 \mu \mathrm{g}$ ) from $E$. coli transformed with the vector containing the AU064475 ferritin cDNA (OsFer2); 3: Soluble proteins (total $5.3 \mu \mathrm{g}$ ) from E. coli transformed with the empty vector. (b) Titration of anti-ferritin antiserum. Western blot of recombinant ferritin (20 $\mu$ g protein in each membrane strip) incubated with pre-immune serum and different dilutions of the anti-ferritin serum obtained after four rabbit inoculations. Arrow indicates the band corresponding to $24 \mathrm{kDa}$.

dicted to be very similar (only three amino acid changes), and since a few sequence mistakes were detected in the amplified OsFer1, only recombinant OsFer2 was used in further steps. A polyclonal antibody against rice ferritin was obtained after four inoculations of a rabbit with the recombinant protein. The anti-ferritin antiserum specifically recognized the recombinant protein at a 1:3,200 dilution, when tested in Western blots (Figure 1b).

To test the antibody ability to recognize ferritin from plant tissues, the anti-ferritin antiserum was used to probe a Western blot containing proteins extracted from rice leaves (BR-IRGA 409 plants exposed to 500 ppm Fe for 9 days) as well as from E. coli transformed with the empty and with the ferritin-expressing vector. The antibody recognized the recombinant protein and a rice protein with the appropriate size (Figure 2). To ensure that the recognized bands are ferritin, pea ferritin was purified and used as positive control (Figure 2). The identity of the purified pea ferritin 
A

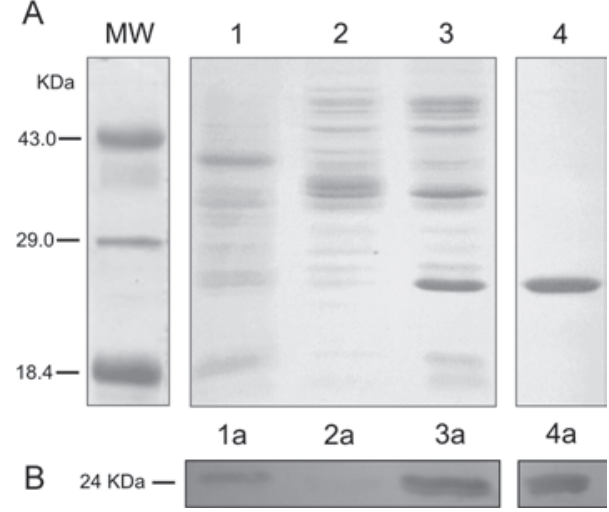

Figure 2 - (A) SDS-PAGE of proteins extracted from rice and $E$. coli BL21(DE3) and (B) Western blot analysis of ferritin protein. MW: molecular weight marker; 1 and 1a: proteins extracted from rice leaves; 2 and 2a: proteins extracted from $E$. coli transformed with the empty vector; 3 and 3a: proteins extracted from E. coli transformed with the vector containing the ferritin gene; 4 and $4 a$ : purified pea ferritin.

was confirmed by the Fe enrichment along the purification process, with purification steps one to four successively yielding $14.9 \pm 7.9 ; 9.6 \pm 1.9 ; 383.9 \pm 57.7$ and 14,151.5 $\pm 880.3 \mathrm{ng}$ Fe per mg protein $(\mathrm{n}=4)$. The polyclonal antibody was unable to recognize 5.8 $\mu \mathrm{g}$ of human ferritin (Biosystems Reagents and Instruments, Barcelona, Spain; standard biological material 94/572 - WHO) in Western blots (data not shown).

Western blots with protein samples from two rice cultivars, I409 and E108, showed higher expression of the ferritin protein under Fe excess than under the control treatment and no expression under Fe deficiency (Figure 3). A slight ferritin induction in the control treatment, in both cultivars, is attributed to the higher Fe availability in the control solution in relation to the growth solution, where plants were kept up to the first harvesting point. Despite the qualitative nature of the Western blot analysis, higher accumulation of ferritin under Fe excess was observed in the E108 cultivar, which is more tolerant to this condition.

Majerus et al. (2007) showed increased ferritin mRNA and protein levels in Oryza glaberrima exposed to nutrient solution with high Fe concentration for 72h. The authors suggested that ferritin synthesis plays important role in the resistance of that species to Fe toxicity. However, no comparison with a non-resistant genotype is available, and it is not possible to establish a clear cause-effect relationship between ferritin accumulation and resistance to Fe toxicity. Susceptible genotypes could also respond to Fe overload with increased ferritin mRNA levels, which would not necessarily be linked to higher amounts of the ferritin pro-

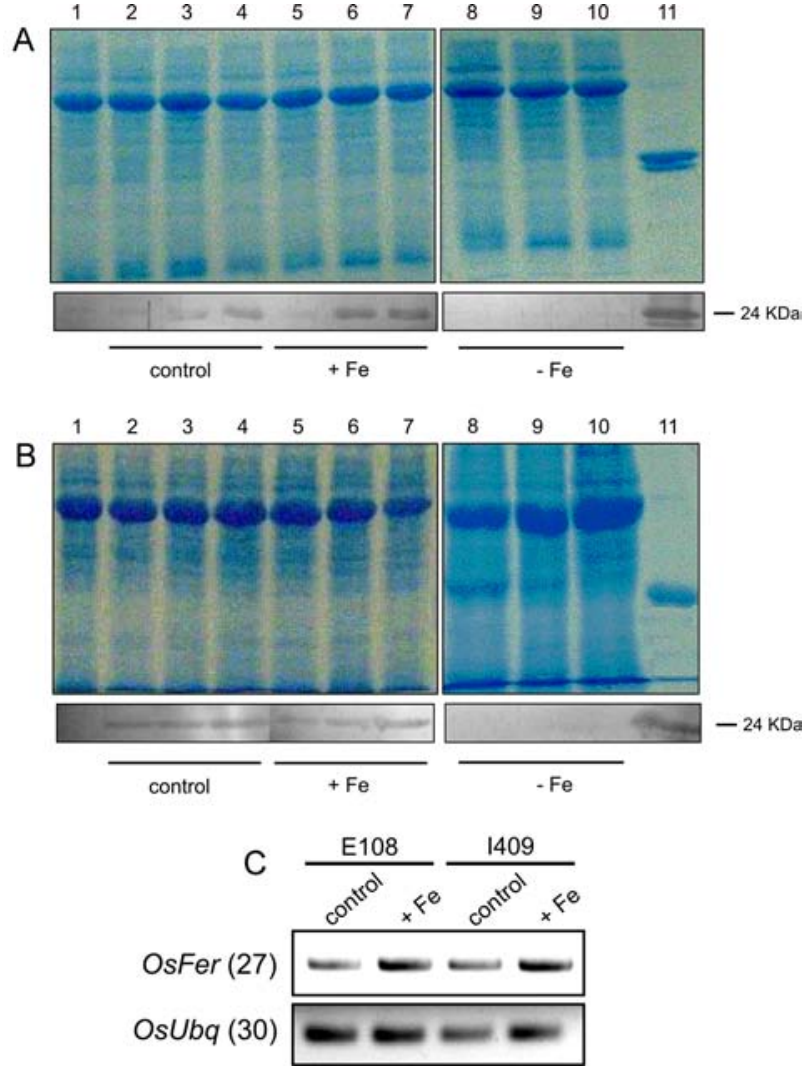

Figure 3 - Ferritin protein and RNA expression in rice leaves. SDS-PAGE and Western blot analysis of proteins extracted from rice leaves from two rice cultivars (A: EPAGRI 108; B: BR-IRGA409) submitted to control, iron overload $(+\mathrm{Fe})$ and iron deficiency $(-\mathrm{Fe})$ conditions ( $25 \mu \mathrm{g}$ of total protein per lane). Protein samples were extracted at the onset of the treatments (1) or after three $(2,5,8)$, six $(3,6,9)$ and nine $(4,7$, 10) days of treatment. Purified pea ferritin $(1 \mu \mathrm{g})$ was used as positive control (11). C: Semi-quantitative RT-PCR from RNA extracted from leaves of I409 and E108 plants exposed to control or iron overload treatments for 9 days. Expression of ferritin mRNAs was evaluated using ubiquitin mRNA levels as control for equal loading. Numbers in parentheses indicate the number of cycles needed to detect the PCR product.

tein. In the present work, two rice cultivars with contrasting levels of tolerance to Fe toxicity were compared, and higher ferritin accumulation in the tolerant genotype was detected, providing clear evidence of the role of ferritin in tolerance mechanisms to Fe overload in rice. The relative importance of ferritin in other rice genotypes, however, needs further investigation in a case-by-case basis, since other factors (Fe exclusion, Fe compartmentalization, enhanced anti-oxidative metabolism, etc) may provide enough resistance to high $\mathrm{Fe}$, even when ferritin levels remain equivalent to the ones found in susceptible genotypes. 
Increased ferritin mRNA levels were seen in leaves of plants exposed to Fe overload (Figure 3c). Since mRNA accumulation was not clearly higher in the tolerant cultivar, the possibility of post-transcriptional regulation of the rice ferritin protein cannot be disregarded. Ferritin post-transcriptional regulation is well known in animals (Petit et al., 2001), but scarce evidence have been documented in plants. The maize ys1 mutant, which has low Fe content in the leaves, accumulates ferritin mRNA but not protein when treated with Fe (Fobis-Loisy et al., 1996). Moreover, there is no direct correlation between the levels of ferritin subunits and mRNA during soybean and maize leaf development, as well as during nodulation in soybean (Briat et al., 2006, and references therein). Further investigation, with quantitative evaluation of gene expression, would be necessary to confirm its occurrence in rice.

Iron concentrations were higher in roots than in shoots, and increased significantly when plants from both cultivars were exposed to Fe excess (Figure 4). In shoots, this treatment resulted in increases higher than 10-fold and 6-fold in I409 and E108 plants, respectively. Seemingly, E108 plants were able to re-
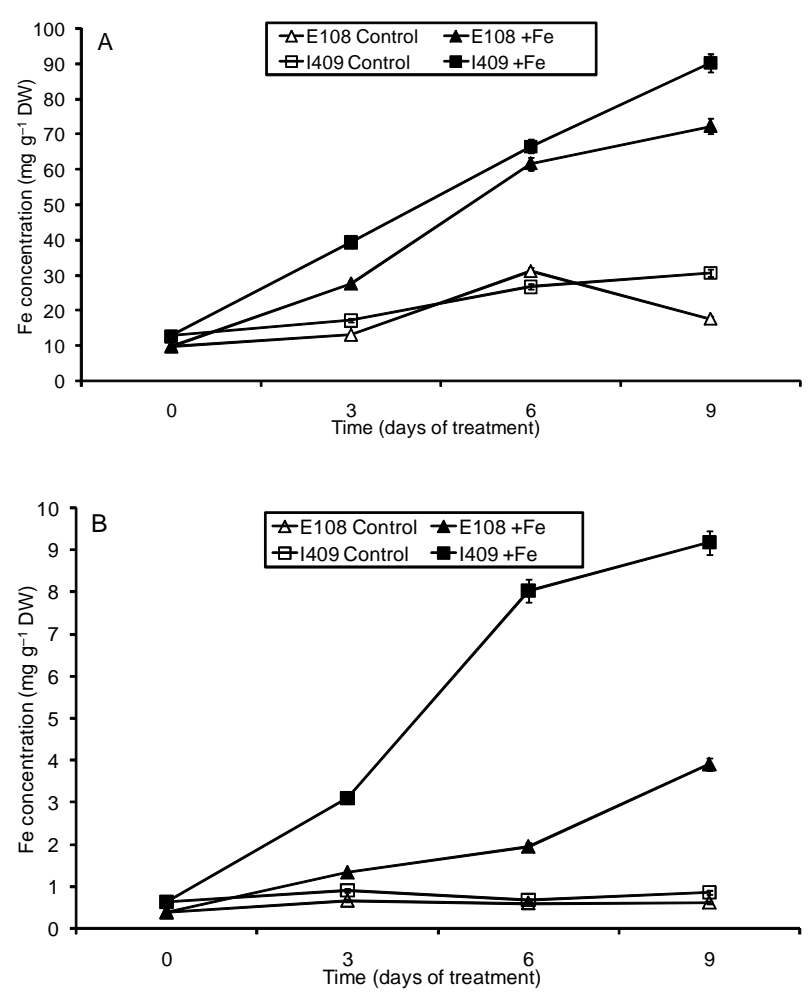

Figure 4 - Iron concentration in roots (A) and shoots (B) of rice cultivars EPAGRI 108 and BR-IRGA 409 submitted to control and iron excess ( $+\mathrm{Fe}$ ) treatments for 3, 6 and 9 days. Error bars stand for the overall uncertainties of the final elemental concentrations, taking into account the variations between independent measurements and the fit uncertainties given by the GUPIX code $(n=3)$. strict Fe accumulation, reaching lower shoot Fe concentrations when submitted to Fe overload than the I409 plants. Silveira et al. (2007) had already suggested that E108 plants rely mostly on avoidance of Fe uptake into the plant and decreased translocation to shoots when coping with Fe overload. Based on results herein presented, we suggest that the tolerance mechanism to excess Fe in E108 includes both restricted $\mathrm{Fe}$ translocation and increased ferritin accumulation.

Rice ferritin in E. coli was successfully expressed and produced a functional antibody which specifically recognized plant ferritin. The antibody allowed to observe increased leaf ferritin protein levels in plants exposed to Fe overload, especially in the tolerant cultivar. This is the first report of increased ferritin protein accumulation in an Fe-overload tolerant Oryza sativa cultivar, providing evidence of a possible role of this protein in Fe tolerance mechanisms.

\section{ACKNOWLEDGEMENTS}

This work was supported by grants and scholarships from CNPq, CAPES and FAPERGS. Authors thank IRGA (Instituto Rio Grandense do Arroz) for the rice seeds and technical assistance.

\section{REFERENCES}

BECKER, R.; MANTEUFFEL, R.; NEUMANN, D; SCHOLZ, G. Excessive iron accumulation in the pea mutants $d g l$ and brz: subcellular localization of iron and ferritin. Planta, v.207, p.217-223, 1998.

BRADFORD, M. A rapid and sensitive method for the quantitation of microgram quantities of protein utilizing the principle of protein-dye binding. Analytical Biochemistry, v.72, p.248254, 1976.

BRIAT, J.F.; CELLIER, F.; GAYMARD, F. Ferritins and iron accumulation in plant tissues. In: BARTON, L.L.; ABADÍA, J. (Ed.) Iron nutrition in plants and rhizospheric microorganisms. New York: Springer, 2006. Chapter 17, p.341-357.

CAMPBELL, J.L.; HOPMAN, T.L.; MAXWELL, J.A.; NEJEDLY, Z. The Guelph PIXE software package. III. Alternative proton database. Nuclear Instruments and Methods in Physics Research. Section B, v.170, p.193-204, 2000.

FOBIS-LOISY, I.; AUSSEL, L.; BRIAT, J.F. Post-transcriptional regulation of plant ferritin accumulation in response to iron as observed in the maize mutant ys1. FEBS Letters, v.397, p.149154, 1996

GENON, J.G.; HEPCEE, N.; DUFFY, J.E.; DELVAUX, B.; HENNEBERT, P.A. Iron toxicity and other chemical constraints to rice land swamps of Burundi. Plant and Soil, v.166, p.109115, 1994

GROSS, J.; STEIN, R.J.; FETT-NETO, A.G.; FETT, J.P. Iron homeostasis related genes in rice. Genetics and Molecular Biology, v.26, p.477-497, 2003.

GUERINOT, M.L.; YI, Y. Iron: nutritious, noxious, and nor readily available. Plant Physiology, v.104, p.815-820, 1994

LAEMMLI, U.K. Cleavage of structural proteins during the assembly of the head of bacteriophage T4. Nature, v.227, p.680-685, 1970. 
LAULHERE, J.P.; LESCURE, A.M.; BRIAT, J.F. Purification and characterization of ferritins from maize, pea, and soyabean seeds. The Journal of Biological Chemistry, v.263, p.1028910294, 1988.

LOBRÉAUX, S.; MASSENET, O.; BRIAT, J.F. Iron induces ferritin synthesis in maize plantlets. Plant Molecular Biology, v.19, p.563-575, 1992.

MAJERUS, V.; BERTIN, P.; SWENDEN, A.; FORTEMPS, A.; LOBRÉAUX, S.; LUTTS, S. Organ-dependent responses of the African rice to short-term iron toxicity: ferritin regulation and antioxidative responses. Biologia Plantarum, v.51, p.303312, 2007.

MIKI, D.; ITOH, R.; SHIMAMOTO, K. RNA silence of single and multiple members in a gene family in rice. Plant Physiology, v.138, p.1903-1913, 2005.

MURGIA, I.; VAZZOLA, V.; TARANTINO, D.; CELLIER, F.; RAVET, K.; BRIAT, J.F.; SOAVE, C. Knock -out of ferritin AtFer1 causes earlier onset of age-dependent leaf senescence in Arabidopsis. Plant Physiology and Biochemistry, v.45, p.898-907, 2007.

NAVA, G.; BOHNEN, H. Iron oxidation on roots of two rice cultivars in flooded soil solution. Revista Brasileira de Ciência do Solo, v.26, p.325-332, 2002.
PETIT, J.M.; BRIAT, J.F.; LOBRÉAUX, M. Structure and differential expression of the four members of the Arabidopsis thaliana ferritin gene family. Biochemical Journal, v.359, p.575-582, 2001.

SAHRAWAT, K.L. Iron toxicity in wetland rice and the role of other nutrients. Journal of Plant Nutrition, v.27, p.14711504, 2004.

SILVEIRA, V.C.; OLIVEIRA, A.P.; SPEROTTO, R.A.; ESPINDOLA, L.S.; AMARAL, L.; DIAS, J.F.; CUNHA, J.B.; FETT, J.P. Influence of iron on mineral status of two rice (Oryza sativa L.) cultivars. Brazilian Journal of Plant Physiology, v.19, p.127-139, 2007.

YOSHIDA, S.; FORNO, D.A.; COCK, J.H.; GOMEZ, K.A. Laboratory manual for physiological studies of rice. Los Banos: IRRI, 1976. 61p.

ZANCANI, M.; PERESSON, C.; PATUI, S.; TUBARO, F.; VIANELLO, A.; MACRI, F. Mitochondrial ferritin distribution among plant organs and its involvement in ascorbate-mediated iron uptake and release. Plant Science, v.173, p.182-189, 2007.

Received July 11, 2008

Accepted December 15, 2008 